and had planned work to reveal the facts. Fortunately the department of dairy husbandry of this institution, under the leadership of Professor C. C. Hayden, has had in progress for many years an investigation with dairy cows contributing evidence directly on this subject; and during the past summer the writer has had under observation this same group of cows on which he was conducting mineral feeding experiments.

Mr. Hayden permits me to make the following observations on these cows. Since 1911 a group of Holstein-Friesian cows has been maintained on dry feeds and silage alone. No green feed has been allowed. Several of the animals now in this group were born in the same and have grown to full maturity without having a bite of green feed. Extensive evidence is at hand, therefore, as to the importance of the suggestion of Hart and associates, as bearing on lactation in cattle.

This group of cows has grown to normal weights, and has produced and reared calves without marked or certain irregularity or abnormality. The milk production has been fair only, it being obvious that.with normal treatment these cows would have given more milk. They do not have normally keen appetites and some are easily forced off feed. They will not eat enough feed to support maximum milk pro̊duction. They fall away during lactation a little more than is customary, but pick up again after going dry. These cows have been in noticeably less thrifty condition, as indicated by flesh and coats, than the balance of the herd, which goes to pasture, and it has been apparent that they crave something which they do not find in the ration.

During the past summer the writer has conducted palatability tests on these cows, with various mineral supplements. They have manifested a keen desire for mineral feeds, having eaten, in several short periods, from approximately three fourths of a pound to more than one and a fourth pounds of mineral supplement per head per day. These supplements have consisted of various calcium phos- phate and carbonate preparations, fed alone or mixed with common salt. It has been shown that the desire of the cows for these feeds has not been wholly or predominantly due to the liking for salt. The avidity with which these cows eat steamed bone, considered in connection with our finding that negative calcium balances normally prevail during lactation in cows on dry feed, and the conclusion of Hart and associates that fresh grass favorably affects calcium retention, suggests that these dry-fed cows are in a state of mineral depletion, especially while giving milk.

It appears, therefore, that the suggestion of Hart and associates is a matter of practical importance as relating to milk production, but that rations of dry feeds and silage, though probably deficient in some constituent, are not entirely lacking in any essential.

The most important work indicating the dependence of calcium metabolism, especially of the teeth, upon vitamines, which has come to the writer's attention is an extensive and unusually successful investigation with guinea pigs (as yet unpublished) by Dr. Percy R. Howe, of Harvard University.

Department OF NUTRTtion,

E. B. Forbes

Ohio Agricultural Experiment Station

\section{SWARMING OF ANOPHELES}

To the Editor of Science: It may seem a little late to publish this note, but, on account of a long absence from the country, I have only just seen reference, in the Review of Applied Entomology for May, 1.920, to Mr. C. S. Banks's article entitled "The Swarming of Anopheline Mosquitoes" published in the Philippine Journal of Science for September, 1919. Mr. Banks is quoted as stating in the article that, although the swarming of mosquitoes has been constantly reported, "no mention seems previously to have been made of this habit in the case of Anophelines." As a matter of fact the late Mr. Frederick Knab published in Psyche for February, 1907, a rather extended note on the swarming of Anopheles maculipennis Say. This note is reprinted in full in the Monograph of the 
Mosquitoes of North and Central America and the West Indies, published by the Carnegie Institution of Washington, and in that cornection observations of a somewhat similar character by several other authors are mentioned (see pages 126-129, Vol. I. of the Monograph).

\section{O. Howard}

\section{THE WORKS OF AMEGHINO}

The Minister of Public Works of the Province of Buenos Aires, Argentine Republic, is financing the publication of a complete edition of the scientific writings and correspondence of Florentino Ameghino (1854-1911) the distinguished S.outh American paleontologist. The editorial work has been undertaken by Alfredo J. Torcelli, and Volumes I. and II. have been issued; though printed in 1913-14 they have just been received. Volume III. will be devoted to "The Antiquity of Man in $\mathrm{La}$ Plata," originally issued in two volumes in 1880-81.

The publication of such a work, stupendous as it is, will prove of inestimable value to those workers who entered the field after Ameghino had published his first papers, copies of which are rarely found in an ordinary scientific library. His writings number 179 essays and books written in Spanish, French and English; some of them large volumes. Ameghino was a voluminous writer and he seldom published short papers. While the number of papers is not large compared to some European writers; Hermann Schaaffhausen for instance, wrote 314 contributions along the lines of anthropology; yet in content they compare favorably with the productions of any one scientific writer of modern times.

The first volume is entitled "Vida y Obras del Sabio," an octavo of 391 pages, printed on a poor quality of paper, and containing a complete account of the life and activities of this noted South American scholar. There is likewise appended a description of the elaborate funeral ceremonies with which his native city nourned the loss of this eminent man.

The second volume with the title: "Primeros
Trabajos Cientificos," is much larger, comprising 770 pages. One regrets the poor quality of the drawings; but it must be remembered that Ameghino's drawings, of which there were thousands, were made by his own hand, untrained to do such work, and under unfavorable conditions, working in the back room of his stationery shop in La Plata. The drawings originally poor and not well produced at first, are not all we would like, but are still of great value as an aid in interpreting Ameghino's ideas.

The third volume will comprise the XXIVth memoir, and since there are 154 memoirs to follow one can, with a little simple mathematics, compute the approximate size of the series. An interesting sidelight to Ameghino's restless mental activity is given in Memoir XXIII., with the title "Taquigrafia Ameghino," which appears to be an attempt on his part to reduce the Spanish language to shorthand'; the characters having a marked resemblance to those used in some American shorthand systems. It is to be hoped that his shorthand system was successful. But of its use in the commercial world of Spanish-speaking peoples, I know nothing. How many living paleontologists have devised a system of such far-reaching importance to another world than their own?

Florentino Ameghino was a wonderful man, and I am sure we wish Alfredo J. Torcelli all the success in the world in his "honorable autant que difficile travail."

Roy L. Moodie

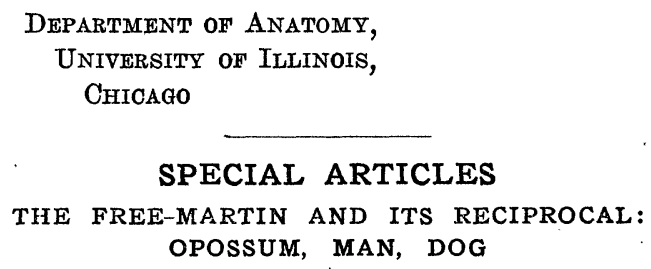

IN 1917 the writer purchased a large fat opossum, presumably a male, but actually a sex-intergrade possessing the following characters: externally, normal penis, empty scrotum, small malformed pouch, head rather like that of a female; internally, reproductive organs distinctly of the female type, infantile 